\title{
Iodothyronine Interactions with the System L1 Amino Acid Exchanger in 3T3-L1 Adipocytes
}

\author{
Fiona E. Mitchell, Lisa A. Roy, and Peter M. Taylor \\ Division of Molecular Physiology, College of Life Sciences, James Black Centre, University of Dundee, Dundee DD1 5EH, UK \\ Correspondence should be addressed to Peter M. Taylor, p.m.taylor@dundee.ac.uk
}

Received 8 December 2009; Revised 30 March 2010; Accepted 4 May 2010

Academic Editor: Masanobu Yamada

Copyright (๑) 2010 Fiona E. Mitchell et al. This is an open access article distributed under the Creative Commons Attribution License, which permits unrestricted use, distribution, and reproduction in any medium, provided the original work is properly cited.

\begin{abstract}
Thyroid hormones enter isolated white adipocytes largely by a System L1-type amino acid transporter en route to exerting genomic actions. Differentiated 3T3-L1 mouse adipocytes in culture express mRNA for LAT1 (the catalytic subunit of highaffinity System L1). L- $\left[{ }^{125} \mathrm{I}\right]-\mathrm{T}_{3}$ uptake into 3T3-L1 adipocytes included a substantial saturable component inhibited by leucine. $\mathrm{L}-\left[{ }^{3} \mathrm{H}\right]$ phenylalanine uptake into $3 \mathrm{~T} 3-\mathrm{L} 1$ cells was saturable $\left(K_{m}\right.$ of $\left.31 \mu \mathrm{M}\right)$, competitively inhibited by $\mathrm{T}_{3}\left(K_{i}\right.$ of $\left.1.2 \mu \mathrm{M}\right)$ and blocked by leucine, $\mathrm{BCH}$, and $\mathrm{rT}_{3}$ as expected for substrate interactions of System L1. Efflux of preloaded L- $\left[{ }^{3} \mathrm{H}\right]$ phenylalanine from 3T3-L1 adipocytes was trans stimulated by external leucine, demonstrating the obligatory exchange mechanism of System L1 transport. $\mathrm{T}_{3}(10 \mu \mathrm{M})$ did not significantly trans stimulate $\mathrm{L}-\left[{ }^{3} \mathrm{H}\right]$ phenylalanine efflux, but did competitively inhibit the trans stimulatory effect of $10 \mu \mathrm{M}$ leucine. The results highlight strong competitive interactions between iodothyronines $\left(\mathrm{T}_{3}, \mathrm{rT}_{3}\right)$ and amino acids for transport by System L1 in adipocytes, which may impact cellular iodothyronine exchanges during altered states of protein nutrition.
\end{abstract}

\section{Introduction}

The thyroid hormones (THs) L-thyroxine and L-triiodothyronine are iodothyronines exerting their major physiological effects by regulation of gene expression in target cells, which they must first enter by crossing the plasma membrane [1-3]. Iodothyronines are now known to translocate cell membranes by a variety of mechanisms, which include the sharing of transport systems for large neutral amino acids (LNAAs; principally aromatic and branched-chain amino acids) and organic anions (see, e.g., [4-6] for review). TH retain a tyrosine-derived amino acid moiety within the iodothyronine molecular structure, allowing them to be accepted as substrates by LNAA transporters such as System L (notably the "System L1" SLC7A5/SLC3A2 heterodimer isoform LAT1) $[7,8]$ and System T (MCT10; SLC16A10) [9].

White adipose tissue is an important target tissue for $\mathrm{TH}$ action, where effects include stimulation of adipogenesis itself [10], modulation of fatty acid synthesis via regulation of expression of lipogenic enzymes [10-12] and modulation of leptin secretion $[13,14]$. TH enter rat adipocytes largely by a System L1-type amino acid transporter [15] and LAT1 mRNA are expressed in rat adipocytes [16]. System L1 is also likely to be of major importance for amino acid metabolism in adipose tissue, which is a site of significant BCAA degradation and utilization for fatty acid and sterol synthesis $[17,18]$. The System L1 substrate leucine in particular appears to be involved in modulation of the mTOR signalling pathway in adipocytes [19]. The activity and expression of System L1 in adipocytes, and its regulation by $\mathrm{TH}$, may therefore be of quantitative importance for whole body iodothyronine and amino acid turnover. In the present study using differentiated 3T3-L1 mouse adipocytes $[20,21]$, we investigate how the mechanism of System L1 transport is influenced by iodothyronines.

\section{Experimental Procedures}

2.1. Materials. L- $\left[2,3,4,5,6-{ }^{3} \mathrm{H}\right]$ Phenylalanine was obtained from Amersham (GE Healthcare, Slough, U.K.) and L$\left[{ }^{125} \mathrm{I}\right]$-Triiodothyronine from PerkinElmer (Bucks, UK). Cell culture media were obtained from GibcoBRL Life Technologies (Paisley, UK) unless stated otherwise; other chemicals 
were obtained from either Sigma Chemicals (Poole, Dorset, UK) or BDH Merck Ltd (Poole, Dorset, UK).

2.2. Cell Culture. 3T3-L1 mouse fibroblasts (ATCC CL-173) were cultured at $37^{\circ} \mathrm{C}, 95 \%$ air: $5 \% \mathrm{CO}_{2}$ in Dulbecco's Modified Eagles Medium (DMEM; high-glucose) with 10\% Donor Bovine Serum (DBS) and 1\% antibiotic/antimycotic (A/A) solution. Before reaching confluence, cells were resuspended by trypsinisation and reseeded into 6- or 12-well experimental plates. To differentiate into adipocytes [22], the 3T3-L1 fibroblasts were grown to confluence (preadipocytes) and then the medium was changed to DMEM with $10 \%$ foetal bovine serum (FBS) and 1\% A/A solution over the duration of the differentiation process. For the first two days of differentiation, $1 \mu \mathrm{g} \cdot \mathrm{mL}^{-1}$ insulin, $5 \mu \mathrm{M}$ isobutylmethylxanthine, and $100 \mathrm{pM}$ dexamethasone were also added to the media and for the subsequent two days $1 \mu \mathrm{g} \cdot \mathrm{mL}^{-1}$ insulin alone was added. The adherent cells were allowed to fully differentiate over a further six days, then used for experiments on days 11 or 12 .

2.3. $\left[{ }^{125} \mathrm{I}\right]-\mathrm{T}_{3}$ and $\left[{ }^{3} \mathrm{H}\right]$ Phenylalanine Uptakes. Immediately prior to an experiment, media was aspirated from the wells and the cells were washed twice in PBS. Transport buffer $\left(121 \mathrm{mM} \mathrm{NaCl}, 4.9 \mathrm{mM} \mathrm{KCl}, 2.5 \mathrm{mM} \mathrm{MgSO}_{4}, 20 \mathrm{mM}\right.$ Tris$\mathrm{HCl}, 1 \mathrm{mM} \mathrm{CaCl}_{2}, \mathrm{pH}$ 7.4) containing either L-[ $\left.{ }^{125} \mathrm{I}\right]-\mathrm{T}_{3}$ at $30 \mathrm{kBq} \cdot \mathrm{mL}^{-1}$ or L- $\left[{ }^{3} \mathrm{H}\right]$ phenylalanine at $18.5 \mathrm{kBq} \cdot \mathrm{mL}^{-1}$ and any other necessary compounds (e.g., inhibitors) were then added to the cells. Once the cells had been incubated in the transport buffer for the designated time period, the buffer was aspirated and the cells were washed quickly three times in cold PBS to halt the uptake process. The cells were then lysed in $1.25 \mathrm{~mL} 50 \mathrm{mM} \mathrm{NaOH}$ overnight at room temperature prior to assay of radioactivity by liquid scintillation counting and determination of protein concentration using Bradford reagent (Biorad UK). Preliminary experiments (data not shown) demonstrated that the uptake of $5 \mu \mathrm{M}\left[{ }^{3} \mathrm{H}\right]$ phenylalanine was linear for at least 5 minutes and therefore, in all subsequent experiments reported here, phenylalanine uptake was measured over a 3-minute period. $\mathrm{L}-\left[{ }^{125} \mathrm{I}\right]-\mathrm{T}_{3}$ uptakes were measured over a 10 -minute period [15]. The specific activity $\left(\mathrm{DPM} \cdot \mathrm{pmol}^{-1}\right)$ of radiotracers was calculated from the radioactivity (DPM) of $10 \mu \mathrm{L}$ transport buffer measured using liquid scintillation counting; tracer uptake is expressed as $\mathrm{pmol} \cdot \mathrm{mg}$ protein ${ }^{-1} \cdot 10 \mathrm{~min}$. For trans stimulation studies, 3T3-L1 adipocytes were preincubated in transport buffer containing $2 \mathrm{mM}$ leucine for $15 \mathrm{~min}$ prior to the initial PBS washes.

2.4. $\left[{ }^{3} H\right]$ Phenylalanine Efflux. 3T3-L1 cells were preloaded with $\left[{ }^{3} \mathrm{H}\right]$ phenylalanine for a period of 15 minutes according to the uptake protocol described above. The radioactive buffer was then aspirated off and the cells were rapidly washed three times with PBS. The cells were then reincubated in (nonradioactive) transport buffer, half of which was removed at timed intervals and immediately replenished with fresh buffer. At the end of each experiment, the remaining buffer was aspirated and the cells lysed overnight in $1.25 \mathrm{~mL} 50 \mathrm{mM} \mathrm{NaOH}$. The incubation buffer aliquots and cell lysates were assayed for radioactivity and the lysate also for protein concentration as described above.

2.5. RNA Extraction and RT-PCR. RNA was extracted from cells using TRIzol Reagent (Invitrogen, Poole, UK) according to the manufacturer's instructions, resuspended in RNasefree $\mathrm{H}_{2} \mathrm{O}$ and quantified by UV spectrometry. $1 \mu \mathrm{g}$ RNA was denatured in the presence of $0.5 \mu \mathrm{g}$ OligodT (Oligo Synthesis Service, University of Dundee) at $70^{\circ} \mathrm{C}$ for $5 \mathrm{~min}$ then reverse-transcribed using Moloney Murine Leukemia Virus Reverse Transcriptase (M-MLV RT) at $100 \mathrm{U} / \mu \mathrm{g}$ RNA in $25 \mu \mathrm{L}$ reaction buffer including $500 \mu \mathrm{M}$ dNTPs (Fermentas) at $42^{\circ} \mathrm{C}$ for 1 hour. The resulting first-strand cDNA was stored at $-20^{\circ} \mathrm{C}$ prior to use in PCR using gene-specific primers to test for specific mRNA expression. The primer sets used in the PCR program were

$$
\begin{array}{lll}
\text { LAT1 } & \text { forward } & 5^{\prime} \text {-tctccttgccattgtcacc-3' } \\
& \text { reverse } & 5^{\prime} \text {-atgactcccaggtggtagttcc-3' } \\
\text { LAT2 } & \text { forward } & 5^{\prime} \text {-aagggaacccgacagcgaaacaac-3' } \\
& \text { reverse } & 5^{\prime} \text {-gggggaagcaggtagggaagagtg- } 3^{\prime} .
\end{array}
$$

For each PCR, $2 \mu \mathrm{L}$ of first strand DNA, $1 \mu \mathrm{M}$ each primer and standard 2x GoTaq Green PCR Master Mix (Promega) were used in a $20 \mu \mathrm{L}$ total volume. The PCR programme used was $95^{\circ} \mathrm{C}, 3 \mathrm{~min} ;\left[94^{\circ} \mathrm{C}, 30 \mathrm{~s} ; 55^{\circ} \mathrm{C}, 30 \mathrm{~s} ; 72^{\circ} \mathrm{C}, 1 \mathrm{~min}\right.$ ] 40 cycles; $72^{\circ} \mathrm{C}, 2$ min using a Thermo Scientific Hybaid Px2 thermal cycler.

2.6. Data Analysis. The data are expressed as means +/S.E.M for $n$ adipocyte preparations. Statistical significance for uptake measurements was assessed by one-way ANOVA followed by a Dunnet post hoc test. For efflux measurements, Graphpad software (San Diego, CA, USA) was used to determine whether the gradients of the lines of best fit (rate constants) were significantly different from control. Differences were considered significant where $P<.05$.

\section{Results}

3.1. $L-T_{3}$ Uptake. The uptake of $50 \mathrm{nM} \mathrm{L-}\left[{ }^{125} \mathrm{I}\right]-\mathrm{T}_{3}$ into 3T3L1 adipocytes included a substantial saturable component, being reduced by around $40 \%$ on addition of $10 \mathrm{uM}$ unlabelled $\mathrm{T}_{3}$ (Figure 1). The magnitude of this saturable component (approximately $1-1.2 \mathrm{pmol} \cdot \mathrm{mg}$ protein ${ }^{-1} \cdot 10 \mathrm{~min}^{-1}$ ) was similar in both adipocytes and pre-adipocytes, although total uptake was about $50 \%$ higher in pre-adipocytes. An excess of the LNAA leucine $(10 \mathrm{mM})$, inhibited over $80 \%$ of saturable $\mathrm{T}_{3}$ uptake (Figure 1). Pre-incubation of 3T3-L1 adipocytes in transport buffer containing $2 \mathrm{mM}$ leucine for 15 minutes (followed by a rapid wash in PBS) resulted in a minor trans stimulatory increase in saturable $50 \mathrm{nM} \mathrm{L}-\left[{ }^{125} \mathrm{I}\right]-$ $\mathrm{T}_{3}$ uptake (by $20 \pm 8.5 \%, n=3$ ), although this increase did not reach statistical significance.

3.2. Phenylalanine Uptake. The uptake of $5 \mu \mathrm{M}$ phenylalanine into $3 \mathrm{~T} 3-\mathrm{L} 1$ cells $(0.465 \pm 0.065 \mathrm{nmol} \cdot \mathrm{mg}$ 


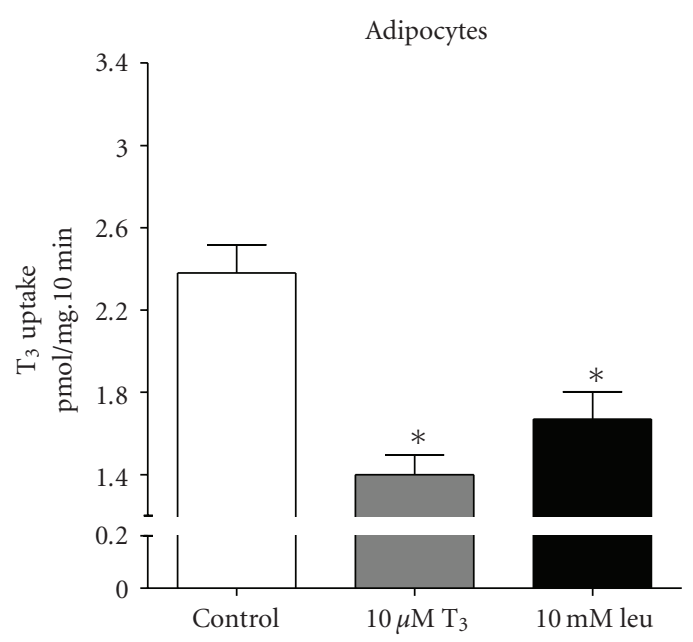

(a)

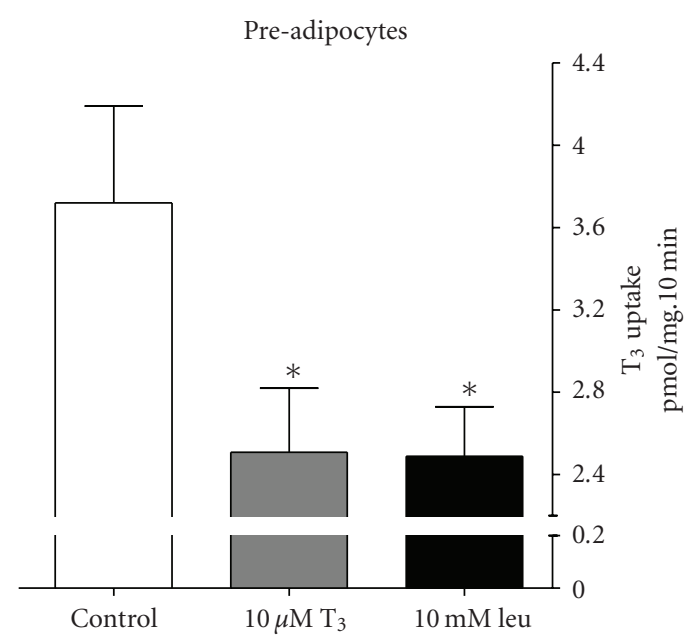

(b)

FIgURE 1: Uptake of the iodothyronine $\mathrm{L}_{-} \mathrm{T}_{3}$ into $3 \mathrm{~T} 3-\mathrm{L} 1$ adipocytes and pre-adipocytes. $\left[{ }^{125} \mathrm{I}\right]-\mathrm{T}_{3}$ uptake was measured at $50 \mathrm{nM}$ over 10 minutes in the absence (control) or presence of $10 \mu \mathrm{M}$ unlabelled $\mathrm{T}_{3}$ or $10 \mathrm{mM}$ leucine in the uptake buffer. Values are expressed \pm SEM of 6-12 measurements. ${ }^{*} P<.05$; value significantly different from control using Dunnett's Multiple Comparison Test.

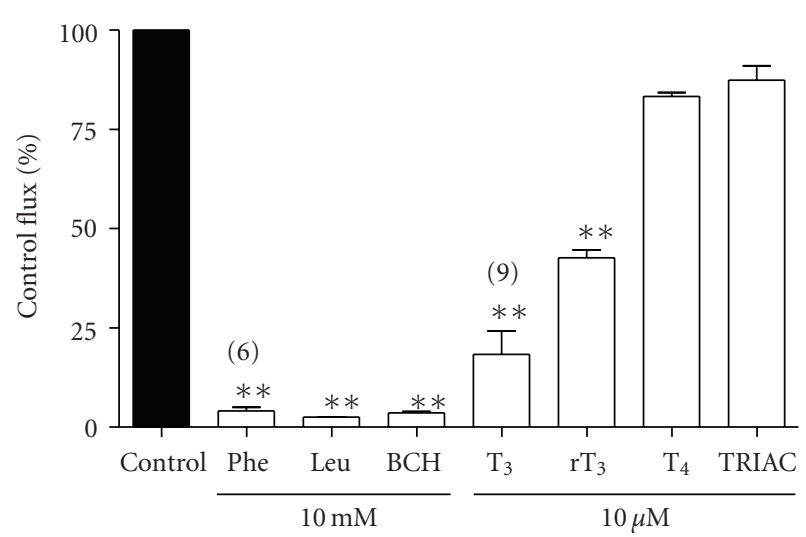

FIGURE 2: Effect of amino acids and iodothyronines on uptake of phenylalanine into 3T3-L1 adipocytes. $\left[{ }^{3} \mathrm{H}\right]$ phenylalanine uptake was measured at $5 \mu \mathrm{M}$ over 3 minutes in the absence (control) or presence of $10 \mu \mathrm{M}$ iodothyronine or $10 \mathrm{mM}$ amino acid in the uptake buffer. Values are expressed \pm SEM of 3 measurements (except where indicated) as $\%$ of the control flux. ${ }^{* *} P<.01$; value significantly different from control using Dunnett's Multiple Comparison Test.

$\left.\operatorname{protein}^{-1} \cdot \min ^{-1}, n=12\right)$ was saturable, being reduced more than $95 \%$ by addition of excess $(10 \mathrm{mM})$ unlabelled phenylalanine, leucine or BCH (2-aminobicyclo-(2,2,1)-heptane2-carboxylic acid; a synthetic System L-type amino acid transport inhibitor) (Figure 2). $5 \mu \mathrm{M}$ phenylalanine uptake was also substantially inhibited by $\mathrm{T}_{3}$ and $\mathrm{rT}_{3}(82 \%$ and $57 \%$ inhibition, resp.) at $10 \mu \mathrm{M}$, although inhibition by $\mathrm{T}_{4}(17 \%)$ and triiodothyroacetic acid (TRIAC; $\mathrm{a} \mathrm{T}_{3}$ analogue lacking the $\alpha$-amino grouping) did not achieve statistical significance at this concentration (Figure 2). Saturable phenylalanine uptake into $3 \mathrm{~T} 3-\mathrm{L} 1$ cells had a $K_{m}$ of $31 \mu \mathrm{M}$ and a $V_{\max }$ of $2.6 \pm 0.5 \mathrm{nmol} \cdot \mathrm{mg}$ protein ${ }^{-1} \cdot \mathrm{min}^{-1}($ mean $\pm \mathrm{sem}, n=6$; see Figure 3 ). The inhibitory effect of $\mathrm{T}_{3}$ on phenylalanine uptake also appeared to be competitive, with a $K_{i}$ of the order of 1-2 $\mu \mathrm{M}$ (see Figure 4).

3.3. Phenylalanine Efflux. Semilogarithmic plots of the cumulative loss of preloaded $\left[{ }^{3} \mathrm{H}\right]$ phenylalanine tracer from 3T3-L1 cells showed that the initial efflux was described by a single rate constant (see Figure 5(a)), indicating that phenylalanine was released largely from a single, freely exchangeable intracellular pool. Efflux of pre-loaded L$\left[{ }^{3} \mathrm{H}\right]$ phenylalanine from 3T3-L1 adipocytes was trans stimulated in a concentration-dependent manner by external leucine (Figure 5(a)). Leucine and tryptophan (both System L substrates) were able to generate over 20 times stimulation of basal phenylalanine efflux (Figure 5(b)). $\mathrm{T}_{3}$ is known to be a substrate for System L1 amino acid transport, so we investigated the ability of $\mathrm{T}_{3}$ to trans stimulate phenylalanine efflux. $\mathrm{T}_{3}$ was unable to significantly trans stimulate L- $\left[{ }^{3} \mathrm{H}\right]$ phenylalanine efflux at $10 \mu \mathrm{M}$ (a concentration approaching the limit of $\mathrm{T}_{3}$ solubility in culture medium), although it did inhibit the trans stimulatory effect of $10 \mu \mathrm{M}$ leucine (see Figure $6(\mathrm{a})$ ). $\mathrm{rT}_{3}$ also inhibited the trans stimulatory effect of $10 \mu \mathrm{M}$ leucine, although $\mathrm{T}_{4}$ did not to any significant degree (Figure 6(a)). The $\mathrm{T}_{3}$ analogue TRIAC (which does not interact with System L1) had no effect on either basal or leucine-stimulated phenylalanine efflux. The effect of $\mathrm{T}_{3}$ upon leucine trans stimulated phenylalanine efflux was found to be concentration dependent (see Figure $6(\mathrm{~b})$ ) with $3.2 \mu \mathrm{M} \mathrm{T} \mathrm{T}_{3}$ able to inhibit $50 \%$ of $10 \mu \mathrm{M}$ leucine trans stimulated phenylalanine efflux, demonstrating the relatively high affinity of $\mathrm{T}_{3}$ for this interaction.

3.4. Transporter mRNA Expression. We detected mRNA for LAT1, but not LAT2 (the alternative catalytic subunit 


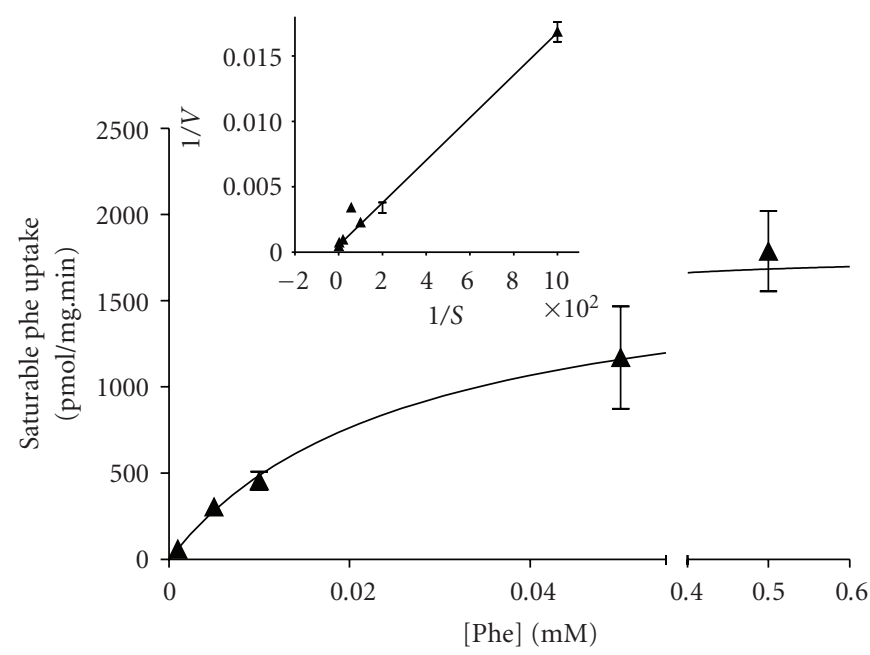

Figure 3: Saturable phenylalanine uptake into 3T3-L1 adipocytes. Uptake of $\left[{ }^{3} \mathrm{H}\right]$ phenylalanine over 3 minutes at 5 different phenylalanine concentrations as indicated (between $1 \mu \mathrm{M}$ and $500 \mu \mathrm{M}$ ) was measured. Values are shown \pm SEM for 3 measurements in a representative experiment and are expressed with the nonsaturable component of uptake removed. Figure inset shows a Lineweaver-Burk plot relating $\left[{ }^{3} \mathrm{H}\right]$-phenylalanine uptake (corrected for nonsaturable component) against external phenylalanine concentration. The overall data provide estimated $K_{m}$ of $31 \mu \mathrm{M}$ and $V_{\max }$ of $2.6 \pm 0.5 \mathrm{nmol} \cdot \mathrm{mg}$ protein ${ }^{-1} \cdot \mathrm{min}^{-1}$ (mean $\pm \mathrm{sem}, n=6$ ).

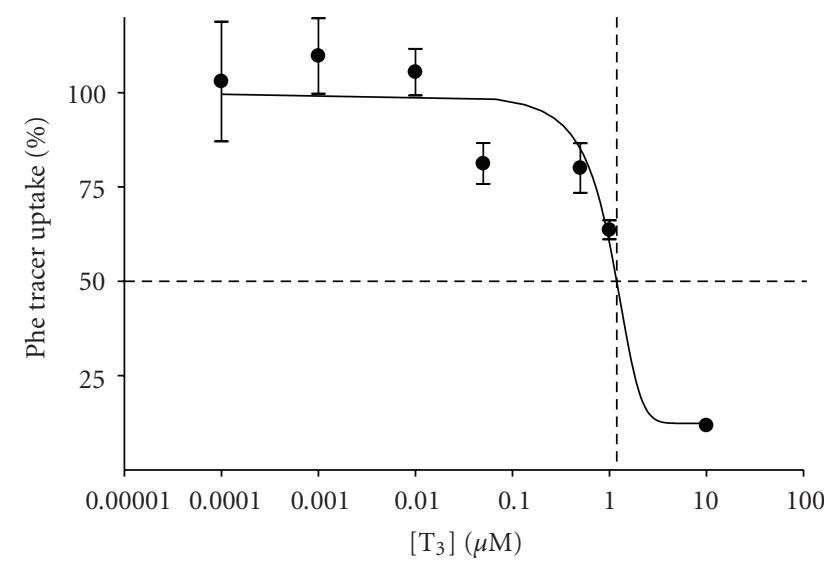

FIgURE 4: Concentration dependence of the inhibitory effect of tri-iodothyronine on phenylalanine uptake into 3T3-L1 adipocytes. Uptake of $\left[{ }^{3} \mathrm{H}\right]$ phenylalanine was measured at $5 \mu \mathrm{M}$ over 3 minutes in the presence of 7 different $\mathrm{T}_{3}$ concentrations as indicated (between $100 \mathrm{pM}$ and $10 \mu \mathrm{M}$ ). Values are expressed as \% of control phenylalanine uptake (measured in the absence of $\mathrm{T}_{3}$ ). The dotted lines indicate that $50 \%$ inhibition is achieved with $1.2 \mu \mathrm{M} \mathrm{T}_{3}$, estimated as the $K_{i}$ for $\mathrm{T}_{3}$ inhibition of phenylalanine uptake in these cells.

producing System L1-type amino acid transport) in 3T3-L1 cells using RT-PCR (see Figure 7).

\section{Discussion}

3T3-L1 cells in culture are used extensively as an in vitro model system for studying white adipose tissue [21] and the present results demonstrate that saturable uptake of the thyroid hormone $\mathrm{L}^{-\mathrm{T}_{3}}$ in both pre-adipocytes and terminally differentiated 3T3-L1 adipocytes occurs largely by a mechanism inhibited by the LNAA leucine, a substrate of the multifunctional System L1 transport system shared by LNAA and iodothyronines (see [6] for review). Saturable uptake processes appear to be the predominant routes of cellular TH entry for genomic signaling via thyroid receptors in animal cells [7]. There appears to be little change in functional expression of saturable $\mathrm{T}_{3}$ transport during adipocyte differentiation (at least for 3T3-L1 cells), which is perhaps unsurprising given that $T_{3}$ is important for the differentiation process itself as well as the control of mature adipocyte functions [10]. The nonsaturable "uptake" of $\mathrm{T}_{3}$ into adipocytes includes surface binding (presumably to secreted lipids and lipoproteins) and partitioning into the lipid bilayer as well as passive diffusion into the cytosol [15]. Transport of phenylalanine (a representative LNAA substrate for Systems L1, L2 and T) in 3T3-L1 adipocytes conforms almost exclusively with "classical" System L1-type function as mediated by LAT1 [23], in that (i) phenylalanine influx has a $K_{m}$ in the low micromolar range $(31 \mu \mathrm{M})$, (ii) it is inhibited by $\mathrm{BCH}$ and (iii) phenylalanine efflux is markedly trans stimulated in a concentration-dependent manner by both leucine and tryptophan (consistent with the obligatory exchange mechanism of System L1 [24]). These features are clearly distinct from those of other likely contributors to phenylalanine transport, specifically because (i) System L2 (LAT3/LAT4) does not recognize tryptophan as a substrate $[25,26]$, (ii) System T (MCT10, originally named TAT1) does not recognize leucine as a substrate $[27,28]$, and (iii) LAT3, LAT4, and MCT10 all utilise facilitative diffusion rather than an exchange mechanism [25-27]. Phenylalanine uptake by $3 \mathrm{~T} 3-\mathrm{L} 1$ cells was competitively inhibited by $\mathrm{T}_{3}\left(K_{i}\right.$ of $\left.1-2 \mu \mathrm{M}\right)$ and $\mathrm{rT}_{3}$ in a manner consistent with expected substrate interactions for the LAT1 System L1 transporter [29-32]. This strong competitive interaction between iodothyronines 


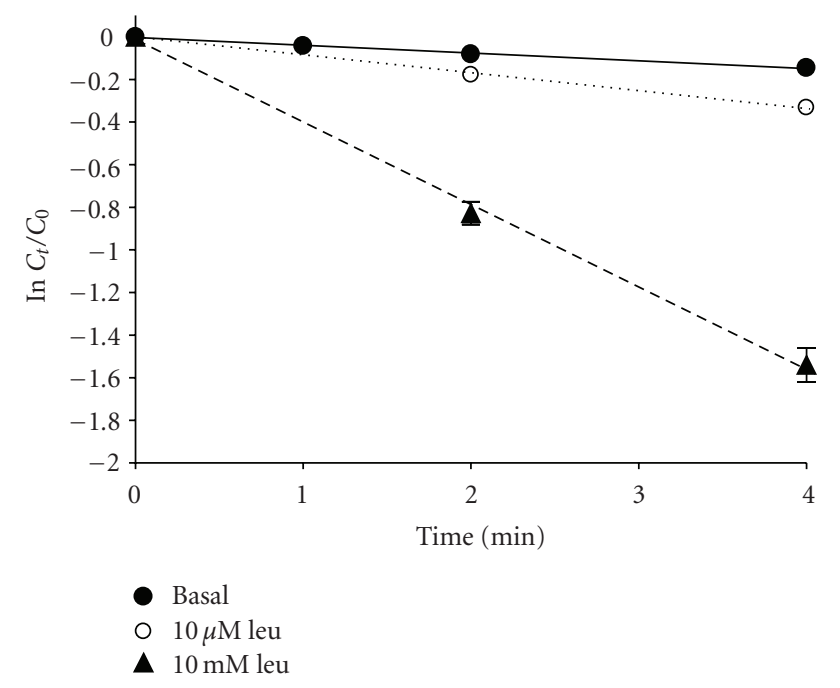

(a)

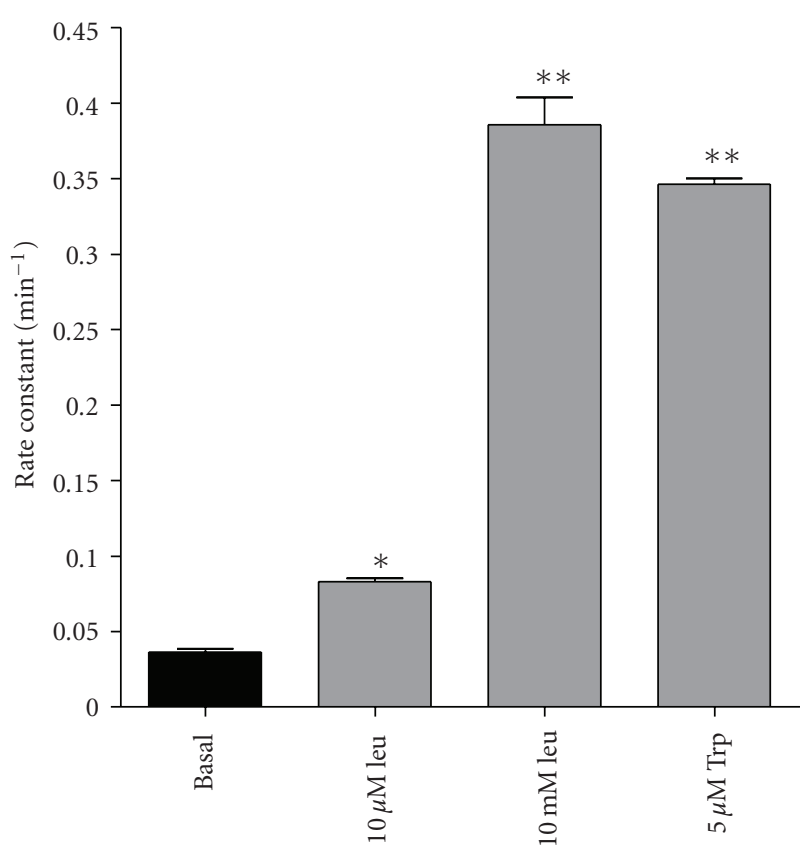

(b)

Figure 5: Phenylalanine efflux from 3T3-L1 adipocytes. (a) Time course of phenylalanine efflux showing the trans stimulatory effect of leucine. The cumulative release of $\left[{ }^{3} \mathrm{H}\right]$ phenylalanine from cells preloaded with the tracer was measured in the presence or absence of extracellular leucine over the time period indicated. Values are shown \pm SEM for 6-18 measurements (smaller error bars are obscured by symbols). $C_{0}$ represents the cellular radioactivity at the start of the experiment and $C_{t}$ is that at time $t$, as calculated from the sum of cumulative radiotracer appearance in the medium and residual cellular radioactivity. The rate constant for efflux was taken as the gradient of the line of best fit. (b) Effects of external amino acids on rate constant for phenylalanine efflux. Bars indicate rate constants calculated as described in (a) and error bars represent SEM for gradient of the line of best fit. ${ }^{*} P<.05$, ${ }^{* *} P<.01$; value significantly different from basal value. and LNAA for transport by System L1 in 3T3-L1 mouse adipocytes is consistent with our previous studies using isolated white adipocytes from rats [15], although the relatively-weak inhibitory effects of $\mathrm{T}_{4}$ in the present study may reflect minor species-specific differences in the relative affinity of different TH for LAT1. The $V_{\max }$ for phenylalanine transport in $3 \mathrm{~T} 3-\mathrm{L} 1$ cells $\left(2.6 \mathrm{nmol} \cdot \mathrm{mg}\right.$ protein $\left.{ }^{-1} \cdot \mathrm{min}^{-1}\right)$ is broadly equivalent to $50 \mathrm{pmol} \cdot 10^{5} \mathrm{cells}^{-1} \cdot \mathrm{min}^{-1}$, a value of the same order of magnitude as that measured for System L1 transport in rat adipocytes [15].

Collectively, our results indicate that the $\mathrm{Na}^{+}$-independent System L1 transporter contributes substantially to iodothyronine and LNAA transport in 3T3-L1 adipocytes and thus for delivery of TH from the plasma to the cytosol, where ultimately they reach the cell nucleus. System L1 has been shown to be an important effector of $\mathrm{T}_{3}$ transport in tissues including placenta and brain as well as adipose ([6] for review). The LAT1 and LAT2 genes encode for alternative catalytic protein subunits of System L1 and these function as heterodimers with $4 \mathrm{~F} 2 \mathrm{hc} / \mathrm{CD} 98$ (see [23] for review). LAT1 and LAT2 both mediate uptake of iodothyronines as well as LNAA $[30,31]$ but while both are expressed in rat adipocytes [16], it appears that only LAT1 is expressed at the mRNA level in 3T3-L1 cells. Our transport studies also indicate the predominant functional expression of LAT1 in 3T3-L1 cells. The $K_{m}$ values obtained for iodothyronine transport by System L1 are substantially lower than those measured for LNAA transport, which help $\mathrm{T}_{3}$ especially to compete effectively with amino acids for transport under physiological conditions (see [6] for review). High-affinity receptors for both $T_{4}$ and $T_{3}$ have been identified associated with the plasma membrane of adipocytes [33] and these may also facilitate preferential iodothyronine uptake [15]. To our knowledge, $\mathrm{T}_{3}$ is the most potent natural inhibitor of System L1 in the mammalian body (and easily surpasses the widely-used synthetic inhibitor BCH in terms of $K_{i}$, if not specificity), although Brasilicardin compounds isolated from bacteria have recently been shown to inhibit with nanomolar potency [34]. Given the therapeutic potential of System L1 inhibitors as immunosuppressants and anticancer drugs $[34,35]$, it is tempting to suggest that the iodothyronine skeleton might be used as a template for improved design of highly specific, non-TH active, System L1 inhibitors. Reverse $\mathrm{T}_{3}$ but not TRIAC (a $\mathrm{T}_{3}$ analog lacking an amino acid moiety which acts as a potent thyroid receptor agonist) interacts with System L1 in adipocytes, demonstrating structural specificity of System L1 which is clearly distinct from that of nuclear thyroid hormone receptors. TRIAC selectively stimulates the metabolic rate of adipose tissue in vivo, a feature considered as a potential tool to increase whole body energy metabolism [13]. It appears from our results that TRIAC enters adipocytes by a different mechanism to $\mathrm{T}_{3}$, which may help explain why TRIAC administered to rats accumulates in white adipose tissue even when coadministered with high $\mathrm{T}_{3}$ doses [13].

The bulky $\mathrm{T}_{3}$ molecule has a much reduced $V_{\max }$ for transport by System L1 compared to LNAA [30], such that its specific interactions with System L1 transport may competitively inhibit not only influx but efflux of 


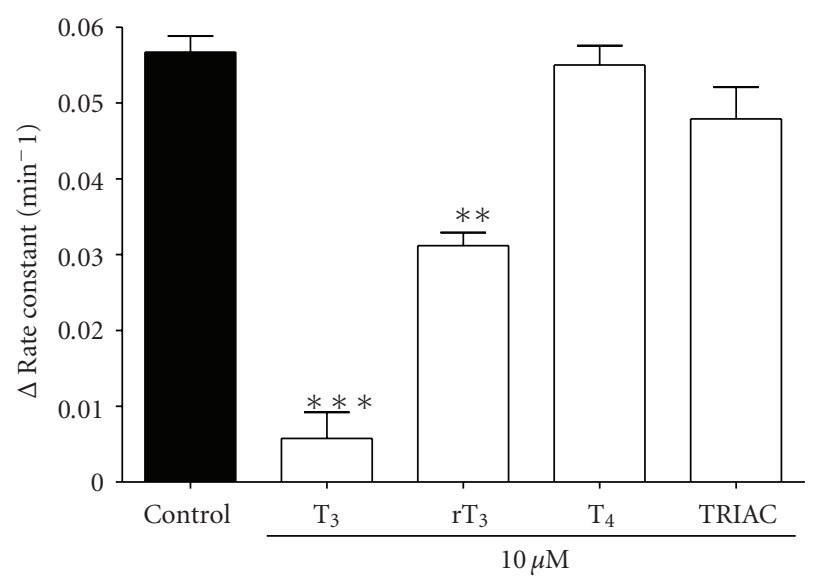

(a)

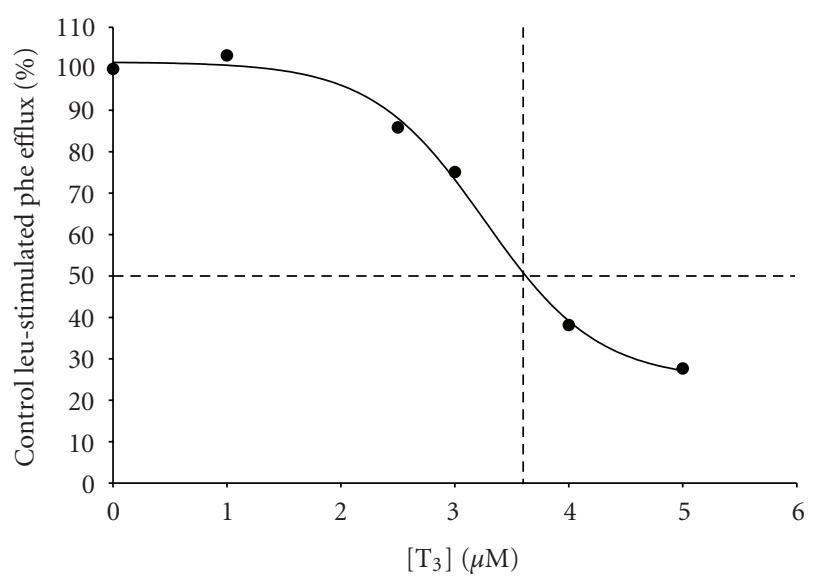

(b)

FIgURE 6: Triiodothyronine inhibits the trans stimulatory effect of leucine on phenylalanine efflux from 3T3-L1 adipocytes. (a) Effect of iodothyronines on leucine trans stimulation of phenylalanine efflux. Release of preloaded $\left[{ }^{3} \mathrm{H}\right]$ phenylalanine tracer from cells was measured in the presence or absence of $10 \mu \mathrm{M}$ leucine \pm either $\mathrm{T}_{3}, \mathrm{~T}_{4}, \mathrm{rT}_{3}$ or TRIAC (each at $10 \mu \mathrm{M}$ ). The rate constants for efflux were calculated as described for Figure 4 and the change in rate constant from control ( $\Delta$ rate constant) was calculated by subtracting the control efflux (without leucine) from that in the presence of leucine \pm iodothyronine/TRIAC. Values are shown \pm SEM for $12-18$ measurements. ${ }^{*} P<.05$, ${ }^{* *} P<.01$; value significantly different from control (leucine only) value. (b) Concentration dependence of $\mathrm{T}_{3}$ inhibition of leucine trans stimulated phenylalanine efflux. Release of preloaded $\left[{ }^{3} \mathrm{H}\right]$ phenylalanine tracer from cells was measured in the presence of $10 \mu \mathrm{M}$ leucine \pm 5 different $\mathrm{T}_{3}$ concentrations (between 1 and $5 \mu \mathrm{M}$ ) as indicated. The rate constants for efflux were calculated as described for Figure 4 and then as the percentage of efflux in the presence of leucine alone. Values are shown \pm SEM for 6 measurements (data points obscure error bars). The dotted lines indicate that $50 \%$ inhibition of $10 \mu \mathrm{M}$ leucine trans stimulated phenylalanine efflux is achieved with $3.2 \mu \mathrm{M} \mathrm{T}_{3}$.

LAT1

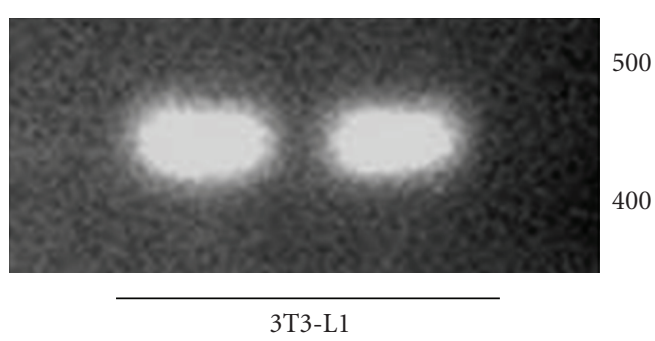

(a)
LAT2

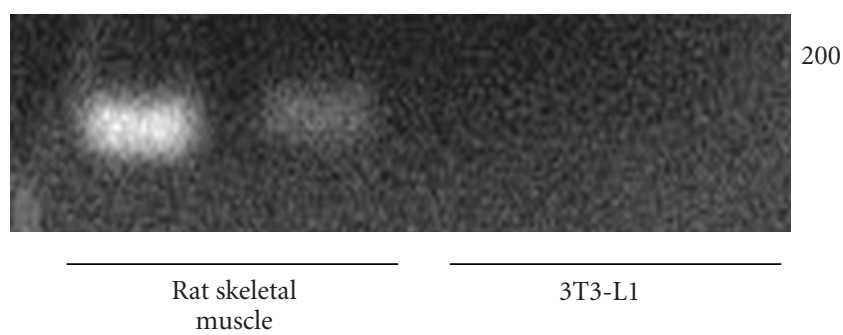

(b)

FiguRe 7: LAT1, a catalytic subunit for System L1 transport, is expressed in 3T3-L1 adipocytes at the mRNA level but LAT2 is not. Reverse transcriptase PCR (RT-PCR) using gene-specific primers designed towards either LAT1 or LAT2 was performed with template cDNA produced from RNA extracted from 3T3-L1 adipocytes. Samples were separated using 2\% agarose alongside a 1kb molecular weight marker (Roche Applied Science). (a) LAT1 mRNA is expressed in 3T3-L1 adipocytes. Following agarose gel electrophoresis, a band of 150 bp was observed corresponding to the expected PCR amplicon using LAT1-specific primers as detailed in the text. (b) LAT2 mRNA is not expressed in 3T3-L1 adipocytes. Following agarose gel electrophoresis, no PCR amplicon was detected when 3T3-L1-derived cDNA was used as a template. However, PCR using LAT2-specfic primers and cDNA derived from rat skeletal muscle did amplify a band of the expected size (465 bp), as shown, which demonstrates the functionality of the primers used.

substrate LNAA by retarding conformational changes of the transport cycle (note the inhibitory action of $\mathrm{T}_{3}$ on leucineinduced trans stimulation of phenylalanine efflux in 3T3L1 cells). Nevertheless, the obligatory exchange mechanism of the System L1 transporter should allow limited LNAAiodothyronine or $\mathrm{T}_{4}-\mathrm{T}_{3} / \mathrm{rT}_{3}$ exchanges across the adipocyte plasma membrane and we indeed observed a minor trans stimulation of saturable $\mathrm{L}_{-} \mathrm{T}_{3}$ uptake in 3T3-L1 adipocytes preincubated with leucine. It is noteworthy in this respect that adipose tissue in vivo releases small quantities of LNAA
[36]. White adipose tissue depots have the capacity to deiodinate iodothyronines (especially $\mathrm{rT}_{3}$ ) $[37,38]$, thus it is conceivable that regulation of iodothyronine turnover in fat cells through this pathway would contribute significantly to modulation of whole body $\mathrm{T}_{4}-\mathrm{rT}_{3}$ metabolism, perhaps particularly in obese individuals. In this respect, downregulation of iodothyronine uptake by System L1 in adipocytes in the hypothyroid state, as reported previously in adipocytes from hypothyroid rats [15], would tend to reduce the sensitivity of adipose tissue to hormonal activation but 
might help conserve hormone and iodine availability to other tissues by reducing their degradation in adipose tissue. Physiological variations in plasma LNAA concentrations, as occurs during natural feeding cycles, may impact TH transport and action in adipose (and other tissues where System L1 is the predominant TH transporter).

\section{Abbreviations}

BCAA: Branched chain amino acids

$\mathrm{BCH}: \quad 2$-amino $[2,2,1]$ heptane-2-carboxylic acid

$\mathrm{T}_{3}$ : L-triiodothyronine

$\mathrm{T}_{4}$ : $\quad$ L-thyroxine

$\mathrm{rT}_{3}$ : Reverse L-triiodothyronine

TH: thyroid hormone

TRIAC: triiodothyroacetic acid.

\section{Acknowledgments}

This paper was supported by the UK BBSRC (FEM) and UK Physiological Society (LAR). The 3T3-L1 cells were a gift from Eric Hajduch, Centre de Recherche des Cordeliers, Paris, France.

\section{References}

[1] G. Hennemann, R. Docter, E. C. H. Friesema, M. De Jong, E. P. Krenning, and T. J. Visser, "Plasma membrane transport of thyroid hormones and its role in thyroid hormone metabolism and bioavailability," Endocrine Reviews, vol. 22, no. 4, pp. 451476, 2001.

[2] B. Gereben, A. M. Zavacki, S. Ribich, B. W. Kim, S. A. Huang, W. S. Simonides, A. Zeöld, and A. C. Bianco, "Cellular and molecular basis of deiodinase-regulated thyroid hormone signaling," Endocrine Reviews, vol. 29, no. 7, pp. 898-938, 2008.

[3] P. M. Yen, "Physiological and molecular basis of thyroid hormone action," Physiological Reviews, vol. 81, no. 3, pp. 1097-1142, 2001.

[4] T. Abe, T. Suzuki, M. Unno, T. Tokui, and S. Ito, "Thyroid hormone transporters: recent advances," Trends in Endocrinology and Metabolism, vol. 13, no. 5, pp. 215-220, 2002.

[5] E. C. H. Friesema, J. Jansen, C. Milici, and T. J. Visser, "Thyroid hormone transporters," Vitamins and Hormones, vol. 70, pp. 137-167, 2005.

[6] P. M. Taylor and J. W. A. Ritchie, "Tissue uptake of thyroid hormone by amino acid transporters," Best Practice and Research: Clinical Endocrinology and Metabolism, vol. 21, no. 2, pp. 237-251, 2007.

[7] J. W. A. Ritchie, Y.-B. Shi, Y. Hayashi, F. E. Baird, R. W. Muchekehu, G. R. Christie, and P. M. Taylor, "A role for thyroid hormone transporters in transcriptional regulation by thyroid hormone receptors," Molecular Endocrinology, vol. 17, no. 4, pp. 653-661, 2003.

[8] J. W. A. Ritchie and P. M. Taylor, "Role of the system L permease LAT1 in amino acid and iodothyronine transport in placenta," Biochemical Journal, vol. 356, no. 3, pp. 719-725, 2001.

[9] E. C. H. Friesema, J. Jansen, J.-W. Jachtenberg, W. E. Visser, M. H. A. Kester, and T. J. Visser, "Effective cellular uptake and efflux of thyroid hormone by human monocarboxylate transporter 10," Molecular Endocrinology, vol. 22, no. 6, pp. 1357-1369, 2008.

[10] M.-J. Obregon, "Thyroid hormone and adipocyte differentiation," Thyroid, vol. 18, no. 2, pp. 185-195, 2008.

[11] N. Pontikides and G. E. Krassas, "Basic endocrine products of adipose tissue in states of thyroid dysfunction," Thyroid, vol. 17, no. 5, pp. 421-431, 2007.

[12] B. Blennemann, P. Leahy, T.-S. Kim, and H. C. Freake, "Tissuespecific regulation of lipogenic mRNAs by thyroid hormone," Molecular and Cellular Endocrinology, vol. 110, no. 1-2, pp. 18, 1995.

[13] G. Medina-Gomez, R. M. Calvo, and M.-J. Obregon, "Thermogenic effect of triiodothyroacetic acid at low doses in rat adipose tissue without adverse side effects in the thyroid axis," American Journal of Physiology, vol. 294, no. 4, pp. E688-E697, 2008.

[14] L. Zabrocka, J. Klimek, and J. Swierczynski, "Evidence that triiodothyronine decreases rat serum leptin concentration by down-regulation of leptin gene expression in white adipose tissue," Life Sciences, vol. 79, no. 11, pp. 1114-1120, 2006.

[15] J. W. A. Ritchie, C. J. F. Collingwood, and P. M. Taylor, "Effect of hypothyroidism on pathways for iodothyronine and tryptophan uptake into rat adipocytes," American Journal of Physiology, vol. 280, no. 2, pp. E254-E259, 2001.

[16] J. W. A. Ritchie, F. E. Baird, G. R. Christie, A. Stewart, S. Y. Low, H. S. Hundal, and P. M. Taylor, "Mechanisms of glutamine transport in rat adipocytes and acute regulation by cell swelling," Cellular Physiology and Biochemistry, vol. 11, no. 5, pp. 259-270, 2001.

[17] P. She, C. Van Horn, T. Reid, S. M. Hutson, R. N. Cooney, and C. J. Lynch, "Obesity-related elevations in plasma leucine are associated with alterations in enzymes involved in branchedchain amino acid metabolism," American Journal of Physiology, vol. 293, no. 6, pp. E1552-E1563, 2007.

[18] H. M. Goodman and G. P. Frick, "Metabolism of branchedchain amino acids in adipose tissue," in Metabolism and Clinical Implications of Branched Chain Amino and Ketoacids, A. P. Walser and A. Williams, Eds., Elsevier, Amsterdam, The Netherlands, 1981.

[19] H. L. Fox, P. T. Pham, S. R. Kimball, L. S. Jefferson, and C. J. Lynch, "Amino acid effects on translational repressor 4E-BP1 are mediated primarily by L-leucine in isolated adipocytes," American Journal of Physiology, vol. 275, no. 5, pp. C1232C1238, 1998.

[20] M. S. O'Shea Alvarez, "3T3 cells in adipocytic conversion," Archivos de Investigacion Medica, vol. 22, no. 2, pp. 235-244, 1991.

[21] T. C. Otto and M. D. Lane, "Adipose development: from stem cell to adipocyte," Critical Reviews in Biochemistry and Molecular Biology, vol. 40, no. 4, pp. 229-242, 2005.

[22] R. Hyde, G. R. Christie, G. J. Litherland, E. Hajduch, P. M. Taylor, and H. S. Hundal, "Subcellular localization and adaptive up-regulation of the system A (SAT2) amino acid transporter in skeletal-muscle cells and adipocytes," Biochemical Journal, vol. 355, no. 3, pp. 563-568, 2001.

[23] F. Verrey, E. I. Closs, C. A. Wagner, M. Palacin, H. Endou, and Y. Kanai, "CATs and HATs: the SLC7 family of amino acid transporters," Pflugers Archiv European Journal of Physiology, vol. 447, no. 5, pp. 532-542, 2004.

[24] C. Meier, Z. Ristic, S. Klauser, and F. Verrey, "Activation of system $L$ heterodimeric amino acid exchangers by intracellular substrates," EMBO Journal, vol. 21, no. 4, pp. 580-589, 2002.

[25] E. Babu, Y. Kanai, A. Chairoungdua, D. K. Kim, Y. Iribe, S. Tangtrongsup, P. Jutabha, Y. Li, N. Ahmed, S. Sakamoto, 
N. Anzai, S. Nagamori, and H. Endou, "Identification of a novel system $\mathrm{L}$ amino acid transporter structurally distinct from heterodimeric amino acid transporters," Journal of Biological Chemistry, vol. 278, no. 44, pp. 43838-43845, 2003.

[26] S. Bodoy, L. Martin, A. Zorzano, M. Palacin, R. Estevez, and J. Bertran, "Identification of LAT4, a novel amino acid transporter with system L activity," Journal of Biological Chemistry, vol. 280, no. 12, pp. 12002-12011, 2005.

[27] T. Ramadan, S. M. R. Camargo, V. Summa, P. Hunziker, S. Chesnov, K. M. Pos, and F. Verrey, "Basolateral aromatic amino acid transporter TAT1 (Slc16a10) functions as an efflux pathway," Journal of Cellular Physiology, vol. 206, no. 3, pp. 771-779, 2006.

[28] D. K. Kim, Y. Kanai, A. Chairoungdua, H. Matsuo, S. H. Cha, and $\mathrm{H}$. Endou, "Expression cloning of a $\mathrm{Na}+$-independent aromatic amino acid transporter with structural similarity to $\mathrm{H}+/$ monocarboxylate transporters," Journal of Biological Chemistry, vol. 276, no. 20, pp. 17221-17228, 2001.

[29] A. M. Mitchell, K. A. Rowan, S. W. Manley, and R. H. Mortimer, "Comparison of mechanisms mediating uptake and efflux of thyroid hormones in the human choriocarcinoma cell line, JAR," Journal of Endocrinology, vol. 161, no. 1, pp. 107$113,1999$.

[30] J. W. A. Ritchie, G. J. Peter, Y.-B. Shi, and P. M. Taylor, "Thyroid hormone transport by 4F2hc-IU12 heterodimers expressed in Xenopus oocytes," Journal of Endocrinology, vol. 163, no. 2, pp. R5-R9, 1999.

[31] E. C. H. Friesema, R. Docter, E. P. C. M. Moerings, F. Verrey, E. P. Krenning, G. Hennemann, and T. J. Visser, "Thyroid hormone transport by the heterodimeric human system L amino acid transporter," Endocrinology, vol. 142, no. 10, pp. 4339-4348, 2001.

[32] J.-P. Blondeau, A. Beslin, F. Chantoux, and J. Francon, "Triiodothyronine is a high-affinity inhibitor of amino acid transport system L1 in cultured astrocytes," Journal of Neurochemistry, vol. 60, no. 4, pp. 1407-1413, 1993.

[33] F. Parl, L. Korcek, J. S. Siegel, and M. Tabachnick, "Uptake of triiodothyronine and thyroxine by isolated rabbit adipocytes," FEBS Letters, vol. 83, no. 1, pp. 145-147, 1977.

[34] T. Usui, Y. Nagumo, A. Watanabe, T. Kubota, K. Komatsu, J. Kobayashi, and H. Osada, "Brasilicardin A, a natural immunosuppressant, targets amino acid transport system L," Chemistry and Biology, vol. 13, no. 11, pp. 1153-1160, 2006.

[35] P. Nicklin, P. Bergman, B. Zhang, E. Triantafellow, H. Wang, B. Nyfeler, H. Yang, M. Hild, C. Kung, C. Wilson, V. E. Myer, J. P. MacKeigan, J. A. Porter, Y. K. Wang, L. C. Cantley, P. M. Finan, and L. O. Murphy, "Bidirectional transport of amino acids regulates mTOR and autophagy," Cell, vol. 136, no. 3, pp. 521-534, 2009.

[36] T. J. Kowalski, G. Wu, and M. Watford, "Rat adipose tissue amino acid metabolism in vivo as assessed by microdialysis and arteriovenous techniques," American Journal of Physiology, vol. 273, no. 3, pp. E613-E622, 1997.

[37] C. F. Wolf and F. S. Keck, "Thyroxine and reverse T3 5 'deiodination in the cells of human adipose tissue," Thyroidology, vol. 3, no. 2, pp. 47-50, 1991.

[38] J. Ukropec, R. P. Anunciado, Y. Ravussin, M. W. Hulver, and L. P. Kozak, "UCP1-independent thermogenesis in white adipose tissue of cold-acclimated Ucp1-/- mice," Journal of Biological Chemistry, vol. 281, no. 42, pp. 31894-31908, 2006. 


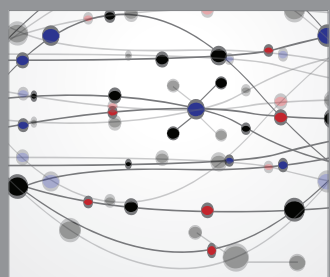

The Scientific World Journal
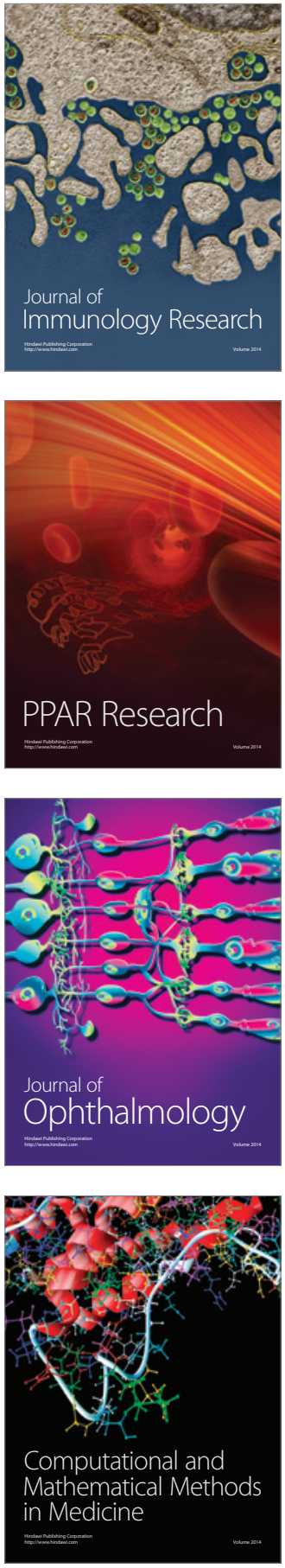

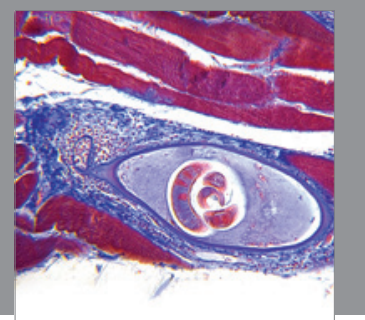

Gastroenterology

Research and Practice
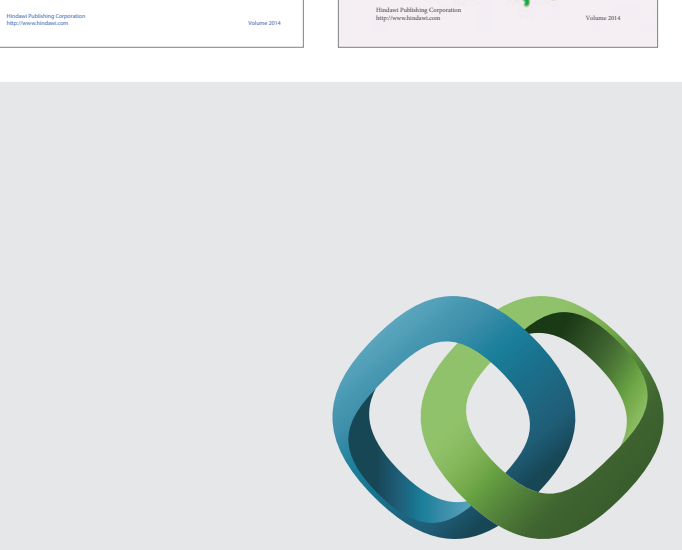

\section{Hindawi}

Submit your manuscripts at

http://www.hindawi.com
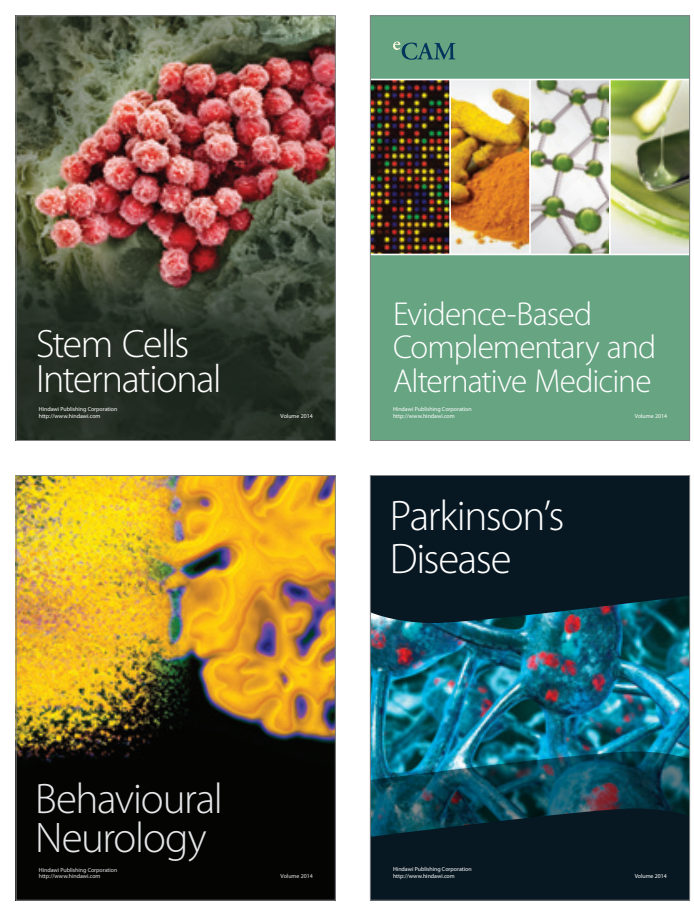

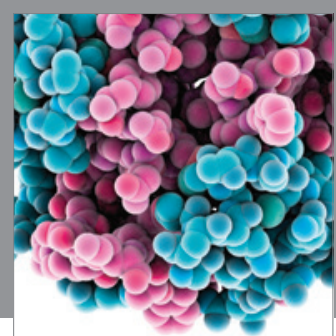

Journal of
Diabetes Research

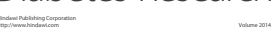

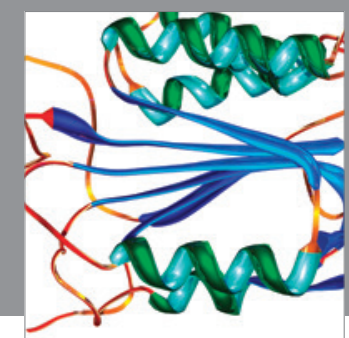

Disease Markers
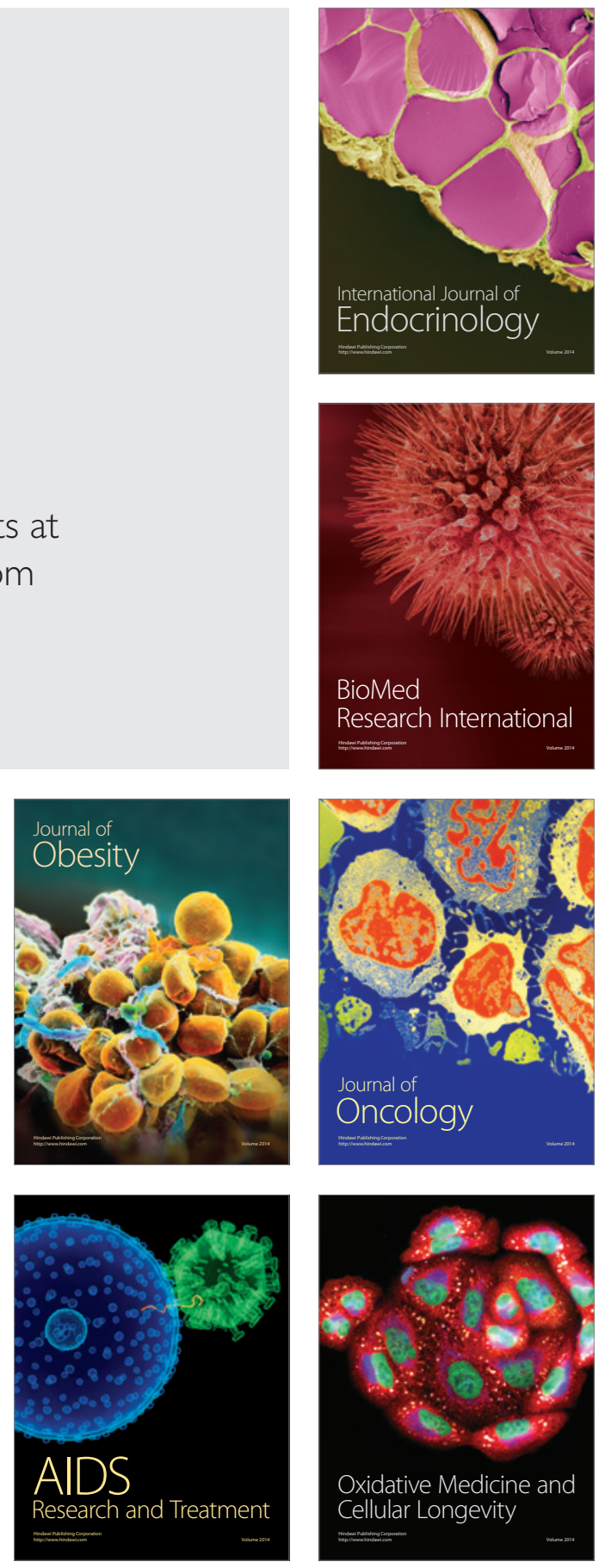